\title{
OBTAINING AND CHARACTERIZATION OF BIODEGRADABLE POLYMERIC
} COMPOSITS PRODUCED WITH AGROENERGETIC WASTE (SUGAR CANE BAGASS, CORN STARCH AND GLYCEROL)

\section{OBTENÇÃO E CARACTERIZAÇÃO DE COMPÓSITOS POLIMÉRICOS BIODEGRADÁVEIS PRODUZIDOS COM RESÍDUOS AGROENERGÉTICOS (BAGAÇO DA CANA-DE-AÇÚCAR, AMIDO DE MILHO E GLICEROL)}

\author{
Roberta Samara Barros Nunes ${ }^{1}$ \\ Alexandre Albuquerque do Nascimento ${ }^{2}$ \\ Juan Carlos Valdés Serra ${ }^{3}$
}

\begin{abstract}
Resumo
O amido, fibra lignocelulósica e plastificante estão conquistando cada vez mais espaço nesse segmento. $\mathrm{O}$ amido, além de ser barato é abundante na natureza, já se destaca na produção de biopolímeros, porém necessitando de tratamento especial, como a adição de fibra e plastificante, para produzir um produto mais resistente. O objetivo deste trabalho foi produzir e caracterizar um material compósito biodegradável fabricado a partir de resíduos agroenergéticos (bagaço da cana-deaçúcar, amido de milho e glicerol). O procedimento baseou-se na técnica de Casting, utilizada em materiais poliméricos que permitem ser derramados por apresentarem baixa viscosidade, obtendo uma forma desejada através da confecção de um molde. Foi produzida a matriz de amido (água, glicerol e ácido acético), chamada formulação controle (FC), com bons resultados nos ensaios mecânicos e posteriormente, produzidos cinco compósitos poliméricos com a aderência da fibra de bagaço de cana-de-açúcar em diferentes percentagens. Os compósitos poliméricos apresentaram altos valores de resistência à tração, e módulo Young, e valores baixos de alongamento na ruptura. Os ensaios de infravermelho mostram bandas semelhantes entre os compósitos, apresentaram também, baixa densidade e solubilidade em água, e alta degradabilidade em solos com alto teor de umidade.
\end{abstract}

Palavras-chave: biopolímeros, biodegradabilidade, amido e propriedades mecânicas.

\footnotetext{
${ }^{1}$ Mestra em Agroenergia e Engenheira Ambiental pela Universidade Federal do Tocantins (UFT), Quadra 109 Norte, Avenida NS-15, ALCNO-14, Plano Diretor Norte, Palmas(TO). ORCID: https://orcid.org/0000-0001-5848-224X . Email: engrobertasamara@gmail.com

${ }^{2}$ Mestre em Química pela Universidade Federal do Maranhão (UFMA), Quadra 109 Norte, Avenida NS-15, ALCNO-14, Plano Diretor Norte, Palmas(TO). E-mail: alexandrejam@uft.edu.br

${ }^{3}$ Doutor em Engenharia Mecânica pela Universidade Estadual de Campinas (UNICAMP). Professor Titular do Programa de Pós-graduação em Agroenergia e da Graduação em Engenharia Ambiental da Universidade Federal do Tocantins (UFT), Quadra 109 Norte, Avenida NS-15, ALCNO-14, Plano Diretor Norte, Palmas(TO). E-mail: juancs@uft.edu.br
} DOI: http://dx.doi.org/10.24021/raac.v18i1.5466

Vol. 18, N. 1 (2021) 


\begin{abstract}
Starch, lignocellulosic fiber, and plasticizers are gaining more and more space in this segment. Starch, in addition to being cheap, is abundant in nature, and stands out in the production of biopolymers, requiring special treatment, such as the addition of fiber and plasticizers, in order to produce a more resistant product. The objective of this work was to produce and characterize a biodegradable composite material made from agroenergetic residues (sugarcane bagasse, corn starch and glycerol). The procedure was based on the casting technique, used in polymeric materials that allow it to be poured by low viscosity, obtaining a desired shape through the making of a mold. The starch matrix (water, glycerol and acetic acid), control formulation (FC), com was produced with good results in the mechanical tests, and later, the five polymeric composites were produced with the adherence of the sugarcane bagasse fiber in different percentages. The polymeric composites have shown high values of tensile strength, and Young module, as well as low values of elongation at break. The infrared assays have shown similar bands between the composites, they have also presented low density and solubility in water, and high degradability in soils with high moisture content.
\end{abstract}

Keywords: biopolymers, biodegradability, starch and mechanical properties.

\section{INTRODUCTION}

Polymeric materials are known to be frequently used in the daily life of our society, and it is possible to note the increase in their use in the most diverse industrial sectors. These materials originate from oil, a non-renewable source and have high resistance to degradation, resulting in their permanence for years in the environment (Mei; Oliveira, 2017). The low degradability associated with the incorrect disposal, the lack of incentive for recycling and the lack of facilities for this environment, result in pollution and contamination of the soil, air and water (Costa et al. 2017).

Therefore, the use of conventional polymeric materials has been discussed and evaluated more frequently in recent years due to all the negative aspects that accompany them. As a consequence, interest has been arising in the production of biodegradable biopolymers, which are polymers from fossil or natural resources, capable of degrading in the environment (Moura et al. 2010). Among the biodegradable biopolymers, polylactic acid (PLA) has become the most commercially attractive option, and it can be obtained through renewable sources, such as corn, sugar cane, and beet. This plastic has mechanical properties similar to polymers from fossil sources, and it is biodegradable in the environment since it is assimilated by living organisms (bacteria) decomposing in about 80 days (Liu et al. 2011). And it already has commercial applications, such as: medical implants, packaging and disposable cutlery, among others (CALABRIA, 2011). However, the growing concern about the scarcity of fossil resources associated with the growth of environmental awareness, demand new methodologies for the production of more sustainable biopolymers.

In this context, there is an interest in the development of polymers that come entirely from 
natural and renewable resources. The combination of starch, lignocellulosic fiber, and plasticizers is gaining more and more space in this segment, and its viability has been proven in several studies, such as those carried out by Fernandes et al. (2019), Costa et al. (2017), Gilfillan et al. (2012), Gilfillan et al. (2014), Debiagi et al. (2010). Starch is a biosynthesized organic carbohydrate abundant in nature, therefore, of low cost, with great potential for use in an industrial scale (Xie et al. 2012). It is also the highlight in the production of biodegradable plastic packaging, although it presents disadvantages when compared to conventional packaging, in relation to the high production cost and low flexibility, with the necessity of special treatments, such as the addition of fibers, plasticizers, and other additives to improve their properties (Salgado et al. 2008; Debiagi et al. 2010).

According to Corradini et al. (2008), starch is easily processed in the presence of a plasticizer, in addition to having polar groups that interact with the hydroxyls of lignocellulosic fibers, and then, result in a material with good mechanical properties. Corn starch, for example, has great prominence in research carried out in the polymeric area, due to the high content of amylose (essential factor for film formation), corresponding to $28 \%$, while cassava starch presents 17\% (Mendes et al. 2012).

Studies indicate that the use of natural fibers, of vegetable or lignocellulosic origin, used as reinforcement in the polymeric matrix, results in materials with better mechanical properties (Masmoudi et al. 2016). Sugarcane bagasse, for example, is a lignocellulosic material, considered the main industrial residue in the sugar and alcohol sector, generated at a rate of $135 \mathrm{~m}^{3} \cdot$ ton $^{-1}$ of sugarcane, however, this material has been valued and transformed into a by-product with added value, as is the case of biopolymers. Thus, allowing the reduction of production costs of biopolymers and, consequently, environmental risks, since the incorrect management of waste would result in serious environmental damage.

Another widely used raw material is glycerol, a co-product of the production of Biodiesel, which acts as a plasticizer that allows the matrix better flexibility. In Brazil, the production of glycerol shows that the supply is greater than the demand, for every $90 \mathrm{~m}^{3}$ of biodiesel produced by the transesterification reaction of vegetable oils, around $10 \mathrm{~m}^{3}$ of glycerin are generated, resulting in the drop in the price of the co-product and the storage without adequate destination. Therefore, it is necessary to seek new applications and markets for glycerin, assigning value to the Biodiesel production chain (Beatriz et al. 2011).

Agroenergetic residues are being recognized as high potential raw materials for the production of biodegradable biopolymers, therefore, research is being carried out based on the adequacy of the optimum conditions of the mechanical properties, suitable plasticizers temperature, time, processability, and rate of degradability, with the objective of producing a product with high quality at an industrial level. Based on this premise, the present work seeks to develop and characterize biodegradable composite materials using natural and renewable resources, such as corn starch, sugarcane bagasse, and glycerol, raw materials that are easily and abundantly found.

\section{MATERIALS AND METHODS}

Corn starch (Maizena brand), glycerol (Cromoline brand), acetic acid (Cromo brand), distilled water and sugarcane bagasse (supplied by the company Bunge, a bioethanol-producing agribusiness, located in the city of Pedro Afonso/TO) were used to develop the work.

\subsection{Fiber treatment}

In order to use the sugarcane bagasse, it was necessary to transform it into powder. For this, the 
bagasse was initially subjected to a drying process in a forced air circulation oven at $60^{\circ} \mathrm{C}$ for a period of approximately $24 \mathrm{~h}$.

Then, the dry material was subjected to the grinding process in a stationary knife mill, using 20 mesh cirvo sieves. Crushing is necessary to reduce the porosity of the material produced, as it can have a negative influence on the mechanical properties of composites made up from natural fibers.

\subsection{Making of composites}

The production procedure was based on the Casting technique (pouring or spilling), used for polymeric materials that allow them to be poured due to their low viscosity, making possible the achievement of a desired shape through the making of a mold. The first stage of the work was based on the production of a polymeric matrix, named as control formulation (FC), produced with corn starch, glycerol, water and acetic acid, as shown in Table 1. After reaching a consistent and malleable matrix, polymeric composites were produced, inserting small variations of matrix and of sugarcane bagasse fiber, according to Table 2.

The solid components were weighed on an analytical balance, the water was added into a beaker cup and heated on a heating plate with constant magnetic stirring until reaching $50{ }^{\circ} \mathrm{C}$, then the starch was added and remained warm until the temperature reached $70{ }^{\circ} \mathrm{C}$ (to guarantee the gelatinization of the starch), afterwards, the acetic acid PA solution and the glycerol PA were added, the acetic acid acts by breaking glycerol connections, facilitating its interaction with the starch. The mixture remaining in agitation up to a temperature range of $80-85^{\circ} \mathrm{C}$. Reaching this limit, stirring was continued until a mixture with a transparent gel-like medium was obtained, at an almost solid shape. During the process, the $\mathrm{pH}$ was adjusted by dripping a 0.1 mol. $\mathrm{L}^{-1} \mathrm{NaOH}$ solution, adjusting it between 6-8. The film-forming solution was spread on petri dishes and dried in an oven with air circulation at $45^{\circ} \mathrm{C}$ for $12 \mathrm{~h}$, then it remained at room temperature for $24 \mathrm{~h}$ and later, the specimens were made for mechanical tests.

Table1. Formulation of the polymeric matrix.

\begin{tabular}{ccccc}
\hline M & $\begin{array}{c}\text { Starch } \\
(\mathbf{g})\end{array}$ & $\begin{array}{c}\text { Water } \\
(\mathbf{m l})\end{array}$ & $\begin{array}{c}\text { Glycerol } \\
(\mathbf{m l})\end{array}$ & $\begin{array}{c}\text { Acetic Acid } \\
(\mathbf{m l})\end{array}$ \\
\hline FC & 5 & 50 & 1 & 1 \\
\hline
\end{tabular}

In order to arrive at the values in Table 1, preliminary tests were necessary to identify how each raw material behaved, the amount of mass that the petri dish could support and the identification of the temperature and time required for production and drying of the formulations resulting in a final product suitable for mechanical tests.

The production of polymeric composites followed the same procedure as the matrix, however, when inserting the sugarcane bagasse fiber in the last stage of the process, the formulation was left for another 10 minutes under agitation at a constant temperature of $80-85^{\circ} \mathrm{C}$. After being removed from the greenhouse and resting for $24 \mathrm{~h}$ at room temperature, the composites were removed from the petri dish and the specimens were made for mechanical tests.

Table 2. Percentage of matrix and fiber from sugarcane bagasse for the production of polymeric composites.

\begin{tabular}{ccc}
\hline Composite & Matrix (\%) & Fiber (\%) \\
\hline C1 & 90,10 & 9,90 \\
C2 & 85,15 & 14,85 \\
C3 & 80,20 & 19,8 \\
C4 & 75,25 & 24,75 \\
C5 & 70,30 & 29,70 \\
C6 & 65,36 & 34,64 \\
\hline
\end{tabular}

Figure 1a presents the viscous solution of the composite, spread by the petri dish with the help of a spatula, before drying in the greenhouse. Figure $1 \mathrm{~b}$ presents the result of the composite after drying and out of the petri dish, ready to produce research evidence and to perform mechanical tests. 
Figure 1. Composite before drying in the greenhouse (a), and after drying (b).

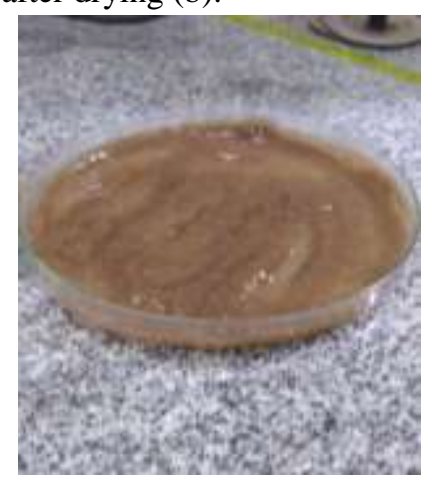

(a)

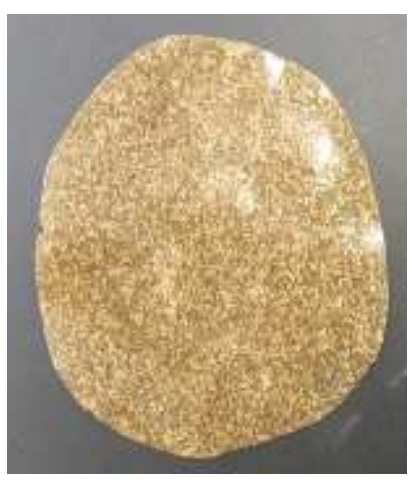

(b)

\subsection{Fouier-transform infrared spectroscopy} (FTIR)

The infrared analysis was carried out at the Research Laboratory of Environmental Chemistry and Biofuels at the Federal University of Tocantins, using equipment with a universal accessory of diffuse reflectance (UATR) and diamond crystal. This technique was used to characterize the functional groups of polymeric composites.

\subsection{Mechanical properties}

The mechanical tests were carried out at the Building Materials Laboratory of the Federal University of Tocantins, using the universal testing machine EMIC DL 2000 with a $5000 \mathrm{~N}$ load cell, claw speed of $4000 \mathrm{~mm} / \mathrm{min}$, based on the standard ASTMD - 638, with modifications. The specimens, the matrix, and the composites, were prepared $60 \mathrm{~mm}$ long and $40 \mathrm{~mm}$ wide, and each treatment was subjected to five repetitions. Thickness, tensile strength, elongation at break, and Young module were analyzed.

The thickness of the composite was measured using a micrometer, representing the arithmetic average of five measurements randomly taken in different parts of the samples.

After identifying the polymeric composite with the best value in mechanical assays, other characterization assays were performed, such as: density, water solubility, biodegradation and scanning electron microscopy (SEM).

\subsection{Density}

The density was carried out using specimens, in triplicate, of $2 \mathrm{~cm} \mathrm{x} 2 \mathrm{~cm}$ of the films, where they were dehydrated in a desiccator containing silica gel for three weeks, then they were weighed and the mass difference was calculated (Muller et al. 2008). The calculation was performed according to Equation 1.

$$
d=\frac{m}{V}=\frac{m}{A \cdot e}
$$

\section{Where:}

$\mathrm{m}$ is the sample's mass.

A is the sample's area.

e is the sample's thickness.

\subsection{Solubility in water}

The water solubility of the films was determined according to the method proposed by Gontard et al. (1994). The samples, in triplicate, were prepared by cutting discs of $2 \mathrm{~cm}$ in diameter. The initial dry mass of the samples was obtained after drying them, for a period of $24 \mathrm{~h}$ at a temperature of 105 ${ }^{\circ} \mathrm{C}$, in an air circulation oven. After the first weighing, the samples were immersed in a container containing $50 \mathrm{~mL}$ of distilled water and stirred gently for $24 \mathrm{~h}$. Then, the samples were removed from the water and dried at a temperature of $105{ }^{\circ} \mathrm{C}$ for another $24 \mathrm{~h}$, in order to obtain the final dry mass.

\subsection{Biodegradability}

The mass loss biodegradation assay was based on the ASTM G 160-03 standard. The assay composition was $2 \mathrm{~kg}$ of dry horse manure, $2 \mathrm{~kg}$ of coarse sand, $2 \mathrm{~kg}$ of fertile soil with low clay content and water for homogenization. Soon after, 
the fertilizer was left to rest for 3 months for maturation, during which time humidity and $\mathrm{pH}$ tests were carried out at a $\mathrm{pH}$ meter once a month. The test was performed in ambient temperature, and kept away from light. Then, the specimens obtaining $60 \mathrm{~mm}$ in length and $20 \mathrm{~mm}$ in width were buried in the soil where the degradation of the composites was analyzed, through visual tests and the observation of the loss of mass of the composites. The weight loss was evaluated in the samples through initial weighing, at zero time of the biodegradation assay and weighing for 60 days. The analysis were performed in triplicate (Chandra \& Rustgi, 1997).

\subsection{Scanning electron microscopy (SEM)}

The microstructure analysis of the films was performed at the Microbiology Laboratory of the University of Brasilia, using a scanning electron microscope. In this way, the samples were visualized for analysis of the surface and the fracture area, identifying and revealing the adherence of the bagasse fiber in the starch matrix.

\subsection{Statistical analysis}

Analysis of variance (ANOVA) was performed using the Tuckey test, with the aid of the SISVAR program. The Tuckey test is used to test any difference between two treatment averages, at the level of $5 \%$ probability $(\mathrm{p}<0.05)$. Six treatments have been considered for the composites, in addition to the control formulation, with the number of five repetitions for each factor analyzed (thickness, tensile strength, elongation at break and Young modulus).

\section{RESULTS AND DISCUSSION}

\subsection{Mechanical properties of composites}

The samples of the control formulation were transformed into specimens and subjected to mechanical assays, the samples had an average thickness of $0.46 \pm 0.02 \mathrm{~mm}$; tensile strength of $15.37 \pm 2.10 \mathrm{MPa}$; elongation at break of $7.272 \pm$ $0.64 \%$ and Young's module of $459.2 \pm 3.33$. In a similar study developed by Sueiro et al. (2016), a variation of 2.05 to $4.82 \mathrm{MPa}$ of tensile strength and 33 to $88 \%$ in elongation at break was obtained. Marengo et al., (2013) reached $2.12 \mathrm{~mm}$ in thickness in cassava films; $13.26 \mathrm{MPa}$ in tensile strength and $1.79 \%$ in elongation at break. Antunes et al. (2019) obtained 7.50 MPa in tensile strength; 9.5\% elongation at break and $155.15 \mathrm{MPa}$ in Young module.

Figure 2 illustrates the polymeric composite ready and out of the petri dish.

Figure 2. Finished composites ready to make the specimens.

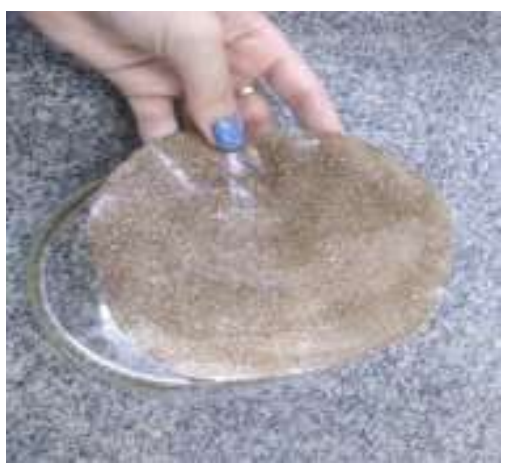

The averages and standard deviations of the six composites specimens, regarding the values of thickness, tensile strength, elongation at break, and Young module, are shown in Table 3. 
Table 3. Average and standard deviation regarding the mechanical properties of the composites.

\begin{tabular}{|c|c|c|c|c|c|c|c|c|}
\hline \multirow{2}{*}{ C } & \multicolumn{2}{|l|}{$\begin{array}{c}\text { Thickness } \\
(\mathbf{m m})\end{array}$} & \multicolumn{2}{|c|}{$\begin{array}{c}\text { Tensile Strenght } \\
\text { (MPa) }\end{array}$} & \multicolumn{2}{|c|}{$\begin{array}{c}\text { Elongation at Break } \\
(\%)\end{array}$} & \multicolumn{2}{|c|}{ Young Module (MPa) } \\
\hline & $0.46 \pm 0.02$ & $\mathrm{a}$ & $15.37 \pm 0.10$ & $\mathrm{~d}$ & $7.272 \pm 0.64$ & $\mathrm{a}$ & $459.2 \pm 3.33$ & $\mathrm{e}$ \\
\hline C1 & $0.52 \pm 0.02$ & $\mathrm{a}$ & $2.284 \pm 0.22$ & $\mathrm{a}$ & $6.239 \pm 1.22$ & $\mathrm{a}$ & $167.1 \pm 58.5$ & $\mathrm{a}$ \\
\hline $\mathrm{C2}$ & $0.56 \pm 0.05$ & $\mathrm{a}$ & $1.694 \pm 0.07$ & $\mathrm{a}$ & $3.545 \pm 0.93$ & $\mathrm{~b}$ & $34.06 \pm 3.06$ & $\mathrm{~b}$ \\
\hline C3 & $0.57 \pm 0.02$ & $\mathrm{a}$ & $1.994 \pm 0.05$ & $\mathrm{a}$ & $7.127 \pm 1.74$ & $\mathrm{a}$ & $35.35 \pm 1.25$ & $\mathrm{~b}$ \\
\hline C4 & $0.58 \pm 0.04$ & $\mathrm{a}$ & $6.282 \pm 1.76$ & $\mathrm{~b}$ & $7.882 \pm 0.94$ & $\mathrm{a}$ & $311.9 \pm 38.4$ & $\mathrm{c}$ \\
\hline C5 & $0.60 \pm 0.12$ & $\mathrm{a}$ & $4.966 \pm 0.14$ & $\mathrm{c}$ & $7.029 \pm 0.72$ & $\mathrm{a}$ & $64.91 \pm 3.78$ & $\mathrm{~d}$ \\
\hline C6 & $0.63 \pm 0.04$ & $\mathrm{a}$ & $18.167 \pm 0.64$ & $\mathrm{~d}$ & $7.678 \pm 0.64$ & $\mathrm{a}$ & $337.1 \pm 14.9$ & $\mathrm{c}$ \\
\hline
\end{tabular}

Note: The averages followed by the same letter in the column do not differ statistically. The Tukey test was applied at the level of $5 \%$ probability $(\mathrm{P} \leq 0.05)$.

Ranging from 0.52 to $0.63 \mathrm{~mm}$, there was no statistic difference. The average tensile strength of composites had a behavior similar to the thicknesses, as the percentage of fiber increased, the strength also increased. An increase of 1.694 to 18.167 MPa was found, C6 obtained the highest value, followed by $\mathrm{C} 4$ and $\mathrm{C} 5$. Both differ statistically.

The elongation at break is the relationship between the elongation of the specimen and its initial length, that is, it measures the ability to stretch. Observing this factor, it appears that only $\mathrm{C} 2$ differed statistically from the others, presenting $3.54 \%$, while the highest value was found in $\mathrm{C} 4$, $7.88 \%$. The Young module, on the other hand, measure the stiffness of the composite, the higher this value, the more rigid it will be. It was found that C4 and C6 stood out, presenting 311.9 and $337.11 \mathrm{MPa}$, respectively. The others had low values.

The tensile strength is directly proportional to the Young module, therefore, the composite that obtained the highest tensile strength also obtained the highest value in the Young module. And both are inversely proportional to the elongation at break. According to the above, it is clear that the C6 stands out with high values of tensile strength and Young module. When compared to the FC, it can be concluded that the adherence of the sugarcane fiber improved the values of tensile strength of the composite (C6), the matrix obtained 15.37 $\mathrm{MPa}$ when added with $34.64 \%$ of fiber, presenting an increase of $2.79 \mathrm{MPa}$, reaching the resistance value of $18.16 \mathrm{MPa}$ (C6). However, there was a small decrease in the value of the Young Module, of $122.2 \mathrm{MPa}$, and a $0.4 \%$ increase in the elongation at break.

In a similar study, developed by Carmo (2016), it was observed that as the percentage of sugarcane bagasse fiber increased, the tensile strength values were significantly improved, when $1 \%$ of fiber was added, a value of $0.42 \mathrm{MPa}$ was obtained, and when added with $3 \%$ fiber it increased to $0.81 \mathrm{MPa}$, that is, there was an increase of $0.39 \mathrm{MPa}$. However, when they increased to $4 \%$ fiber, it was noted that there was no increase in tensile strength. They also observed that the elongation at break decreased as the percentage of fiber increased.

Analyzing another work in the literature Gilfillan et al. (2012) using sugarcane bagasse fibers in potato and corn starch films, it was observed that the addition of $5 \%$ of fiber increased the tensile strength in $16 \%$ when compared to films without fibers, and there was a $43 \%$ decrease in elongation at break. However, when $10 \%$ and $20 \%$ fiber were added, it was noted that the tensile strength and elongation at break decreased. The authors justified these results to the non-uniform dispersion of the fiber and its aggregation. 
In another study, Gilfillan et al. (2014), the production of films consisting of potato starch and sugarcane nanofibers, obtained satisfactory results with the addition of 10 to $20 \%$ of fiber, with resistance increased by $100 \%(3.1-6.2 \mathrm{MPA})$ and the Young modulus increased by up to $300 \%$ (66.3 - 198.3 MPa).

It is evident that in this work the addition of sugarcane fiber contributed positively to the mechanical properties when the percentage of $34.64 \%$ was used, the others were not sufficiently attended.

\subsection{Fouier-transform infrared spectroscopy (FTIR) of composites}

The infrared characterization allows the determination of the functional groups present in the composites. The main bands attributed to this material can be seen in Figure 3.

Figure 3. FTIR spectra of composites.

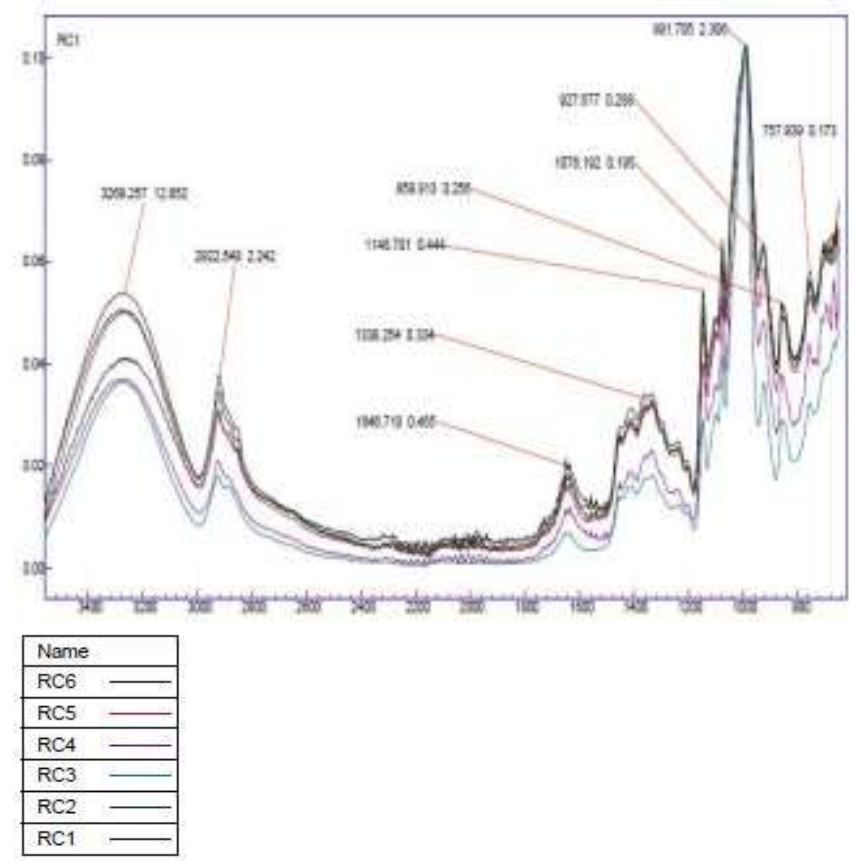

Observing the results, it is possible to verify that the composites had a similar behavior with each other, with small differences in the value of the bands. By analyzing Table 4, it can be seen that the $991 \mathrm{~cm}-1$ band obtained the highest peak.
Table 4: Wave numbers and assignments identified in the composites.

\begin{tabular}{cc}
\hline Wave number $\left(\mathbf{c m}^{-1}\right)$ & Atribution \\
\hline 3229 & Axial deformation O-H \\
2922 & Axial deformation C-H \\
$1646-1338$ & Axial deformation and out of C-H \\
plan \\
$\mathbf{8 5 9 - 9 9 1}$ & $\begin{array}{c}\text { Angular C-H deformation of } \\
\text { alkenes }\end{array}$ \\
$\mathbf{1 0 7 6}$ & Axial deformation C-O \\
\hline
\end{tabular}

Similar results were found in the studies by Marengo et al. (2013), they produced biodegradable composites with cassava and sugarcane starch, in the spectra the broad absorption band corresponding to the $\mathrm{OH}$ stretch was observed, according to the authors indicate the occurrence of hydrogen bridge interactions between the components of the composite during processing. They have also presented bands close to $1600-1640 \mathrm{~cm}^{-1}$, related to the angular fold of $\mathrm{OH}$ in water molecules, indicating the formation of interaction of water with the components of the formulations (starch, glycerol and fiber) (Mano, 2000).

\subsection{Density and solubility in water}

The density, water solubility, biodegradability and scanning electron microscopy (SEM) tests were performed in triplicate, using the composite that showed the best result in the mechanical assays (C6).

The density and solubility values of the composite are shown in Table 5.

Table 5. Averages of density and solubility in water.

\begin{tabular}{ccc}
\hline Samples & $\begin{array}{c}\text { Density } \\
\left(\mathbf{g . c m}^{-3}\right)\end{array}$ & Solubility (\%) \\
\hline C6 & $1.47 \pm 0.02$ & $6.87 \pm 1.38$ \\
\hline
\end{tabular}

The density values of the samples indicated that there was reproducibility in the process of preparing the composites. Similar values were 
found by Almeida et al. (2013), where they produced films with potato starch and cellulose, with a density between 0.43 to $1.72 \mathrm{~g} . \mathrm{cm}^{-3}$, such values are higher than those found by Debiagi et al. (2010), who studied materials based on cassava starch using sugar cane fiber and oat hulls, obtaining density values, respectively, between 0.89 to 0.91 g.cm ${ }^{-3}$ and 0.86 a 0.97 g.cm ${ }^{-3}$. While Schmidt \& Laurindo (2010), who studied materials based on cassava starch and cellulose fibers, found density values between 0.63 and $1.3 \mathrm{~g} . \mathrm{cm}^{-3}$.

The water solubility tests indicated that the composites are soluble in water, which can be explained by the use of glycerol, which has a great influence on the solubility of starch films, due to its hydrophilic character. Glycerol interacts with the film matrix, increasing the free space between the chains, allowing water to enter and, consequently, providing solubility (Machado et al. 2014). The tests also indicated a small variation between samples, ranging from 5.48 to $8.24 \%$. After the rehearsals, the films were whole, however, fragile and breakable. Low values were also found by Debiagi et al. (2010), the solubility of cassava starch samples with sugar cane fiber showed values between 1.44 to $4.66 \%$ and with oat husk fiber between 1.58 to $3.25 \%$. The results found by Machado et al. (2014) corresponded between 12.05 to $23.11 \%$, these produced films of cassava starch with green coconut fiber.

\subsection{Biodegradability}

The samples were buried in the soil with humidity of $18 \%, \mathrm{pH} 8.35$ and temperature 24.06 ${ }^{\circ} \mathrm{C}$, and were totally degraded in a period of $72 \mathrm{~h}$, a consequence of a high level of humidity in the soil. In search of new results, a new biodegradation assay was performed using a new soil with a moisture content of $0.66 \%$ and $\mathrm{pH} 8.34$ where it was possible to extend the test period, lasting two months (Dec / Jan), after this period, it was evaluated through visual observations that the samples remained intact, not obtaining any fragments, however they were hard and brittle.

According to Jayasekara et al. (2005), the main change that a degradable polymer undergoes is the decrease in molecular weight, for this reason, Table 6 was developed, where it is possible to analyze the mass loss of composites.

Table 6. Sample weights before and after biodegradability tests.

\begin{tabular}{cccc}
\hline & \multicolumn{3}{c}{ 2 month period } \\
\hline \multirow{2}{*}{ Samples } & Initial & Final & \% of mass \\
weight $(\mathrm{g})$ & weight $(\mathrm{g})$ & loss \\
C6 & $0.45 \pm 0.05$ & $0.25 \pm 0.03$ & $53 \% \pm 0.22$ \\
\hline
\end{tabular}

In a study by Machado et al. (2014), biodegradable starch composites were produced with the addition of green coconut nanocellulose, plasticized with glycerol in different concentrations, submitted to a biodegradation study in soil at $30^{\circ} \mathrm{C}$ over 17 weeks, presenting a mass loss of approximately $80 \%$ after 119 days.

\subsection{Scanning electron microscopy (SEM)}

Scanning electron microscopy (SEM) images of the surface and fracture of the composites (C6) are shown in Figure 4, 5 and 6. In general, a rough and depressed appearance is seen in the images. 
Figure 4. Rough surface and presence of groove.

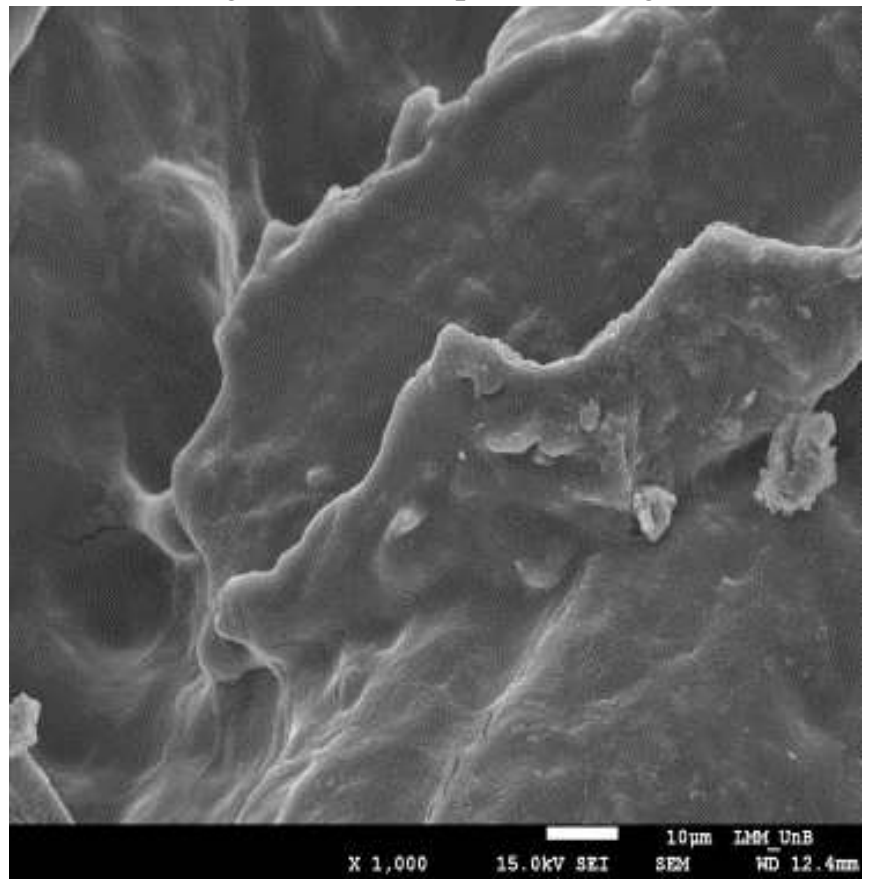

The figure 4 shows the presence of an irregular structure with reliefs and grooves, occasioned by the possible formation of microbubbles during the process of gelatinization.

Figure 5. Surface with presence of starch granule.

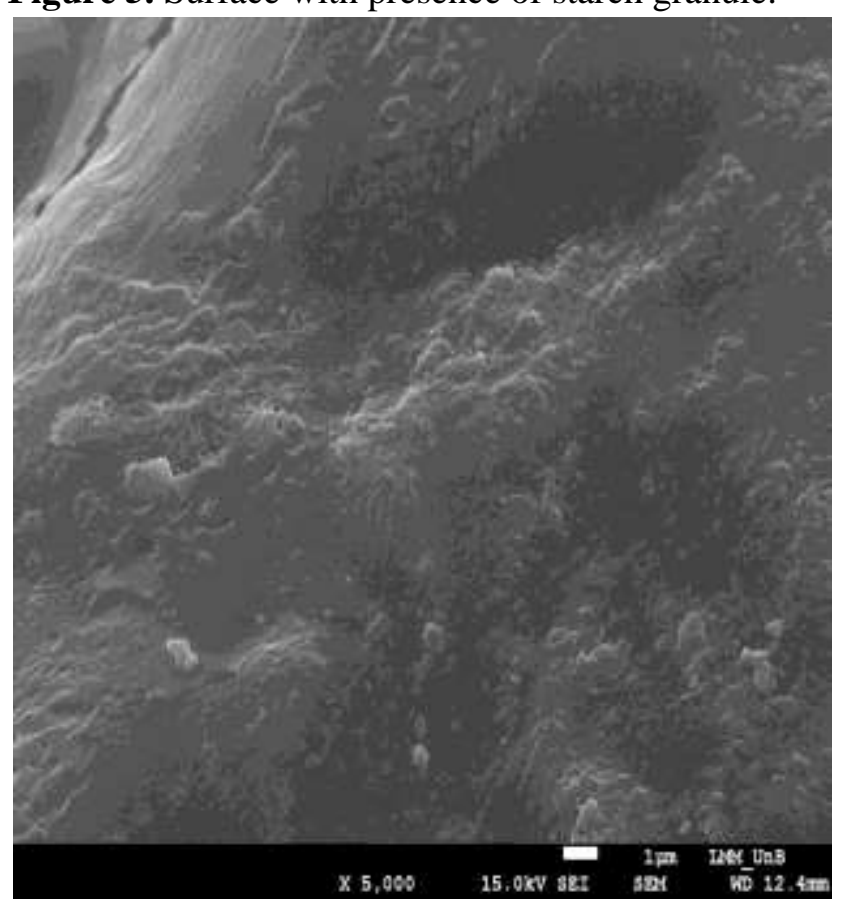

In Figure 5 the presence of intact starch granules, meaning that the starch was not fully gelatinized during the film production process, resulting in a reduction in the flexibility and elongation strength, generating a less cohesive matrix.

Figure 6. Adherence to the fiber in the matrix

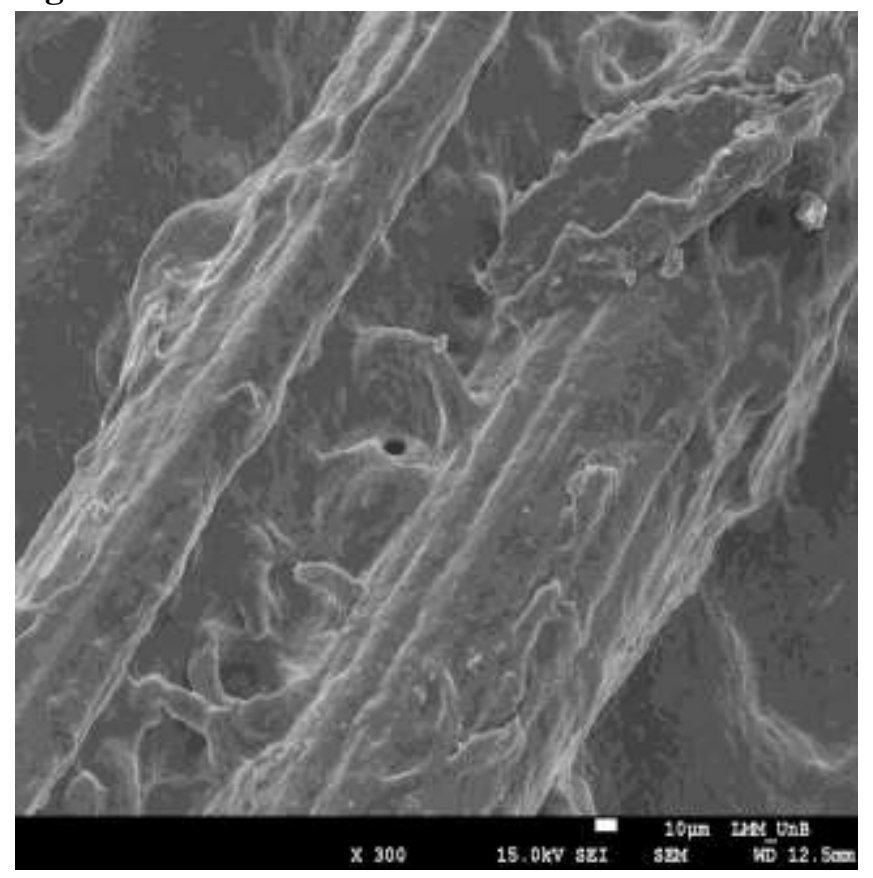

In Figure 6 the presence of fiber in the polymer matrix was randomly observed. A high degree of roughness and irregularities was also observed, which can help the mechanical anchoring of the fiber to the polymeric matrix. In the study by Carmo (2016), the presence of fiber in the polymer matrix was randomly observed. A high degree of roughness and irregularities was also observed, which can help the mechanical anchoring of the fiber to the polymeric matrix.

\section{CONCLUSION}

- It was possible to achieve a formulation for the production of a starch matrix and a polymeric composite using corn starch, glycerol, water, 
acetic acid and sugarcane bagasse.

- The fiber acted as a reinforcement, improving the mechanical properties of a composite.

- The interaction between the raw materials promoted a water-soluble composite, allowing its application as food packaging, consumed together with the food;

- Can also be used as biodegradable bags for plant seedlings.

\section{ACKNOWLEDGEMENT}

This study was financed in part by the Coordenação de Aperfeiçoamento de Pessoal de Nível Superior - Brasil (CAPES). To the translator of this article Victor Chiang Braga Barroso Mendes for the excellent work.

\section{REFERENCES}

ALMEIDA, M. D., WOICIECHOWSHI, L. A., WOSIACKI, G., PRESTES, A. R. \& PINHEIRO, A. L. (2013). Propriedade físicas, químicas e de barreiras em filme formados por blenda de celulose bacteriana e fécula de batata. Polímeros, v. 23, n. 4.

ANTUNES, L. B., et al. Efeito do glicerol nas propriedades mecânicas de filmes a base de quitosana. Revista Desafios, Goiania, v. 6, fev. 2019.

ASTM - American Society for Testing and Materials. Standard Test for Tensile Properties of Plastics D-638-02. Philadelphia: ASTM, 2002.

ASTM - American Society for Testing and Materials. "ASTM G 160 - 03. Standard pratice for Evaluating Microbial Susceptibility of Nonmetallic Materials By Laboratory Soil Burial v. 14.04" (2004).
BEATRIZ, A., ARAÚJO, Y. J. K. \& LIMA, D. P. (2011). Glicerol: Um Breve Histórico e Aplicação em Sínteses Estereosseletivas. Química Nova, v. 34, n. 2, p. 306-319.

CALABRIA, L. (2010). Blendas de biopolímeros para liberação controlada de agroquímicos. 2010. 108 f. Dissertação de Mestrado - Programa de Pós-Graduação em Materiais, Universidade de Caxias do Sul, Caxias do Sul.

CARMO, P. K. (2016). Desenvolvimento e caracterização de filmes poliméricos de amido de milho nativo e modificado com incorporação de fibras de bagaço de cana-de-açúcar e óleos vegetais. Dissertação de Mestrado - Universidade Federal de São Carlos. Sorocaba.

CORRADINI, E., MORAIS, L. C. DE., AGNELLI, J. A. M. \& MATTOSO, L. H. C. (2008). Estudo das propriedades de compósitos biodegradáveis de amido/glúten de milho/glicerol reforçados com fibras de sisal. Polímeros, [s.l.], v. 18, n. 4, p.353358.

COSTA, D. M. A. DA., SANTOS, A. F. DOS., SILVA, E. D. DA. \& SILVA, I. A. DA. (2017). Desenvolvimento e caracterização de filmes à base de amido de feijão macáçar (vigna unguiculata). Holos, [s.1.], v. 7, p. 2.

CHANDRA R. \& RUSTGI R., (1997). Biodegradation of maleated linear low-density polyethylene and starch blends. Polymer Degradation and Stability, v. 56, 185-202.

DEBIAGI, F., MALI, S., GROSSAMANN, M. V. E. \& YAMASHITA, F. (2010). Efeito de fibras vegetais nas propriedades de compósitos biodegradáveis de amido de mandioca produzidos via extrusão. Ciência e Agrotecnologia, v. 34, n. 6, p.1522-1529.

FERNANDES, A. C., CARDOSO, J. C. O., GOMES, J. N. \& ASCHERI, D. P. R. (2019). Elaboração e caracterização de filmes biodegradáveis de amido de Solanum lycocarpum St.Hill e glicerol. Journal of Social, Technological and Environmental Science, v. 8, 
n. 1, p. $362-378$.

GILFILLAN, W; N., NGUYEN, D. M. T., SOPADE, P. A. \& DOHERTY, W. O.S. (2012); Preparation and characterisation of composites from starch and sugar cane fibre. Industrial Crops And Products, [s.1.], v. 40, p. 45-54.

GILFILLAN, W. N., MOGHADDAM, L. \& DOHERTY, W. O. S. (2014). Preparation and characterization of composites from starch with sugarcane bagasse nanofibres. Cellulose, v. 21, n. 4, p. 2695-2712.

GONTARD, N., GUILBERT, S. \& CUQ, J. L. (1994). Water and glycerol as plasticizers affect mechanical and water vapor barrier properties of an edible wheat gluten film. Journal of Food Science, v.58, n.1, p.206-211.

LIU, H.; SONG, W.; CHEN, F.; GUO, L.; ZHANG, J. (2011). Interaction of microstructure and interfacial adhesion on impact performance of polylactide (PLA) ternary blends.

Macromolecules. v. 44, n. 6.

JAYASEKARA, R., HARDING, H., BOWATER, I.; LONERGAN, G. \& CHISTIE, G. J. (2005). Biodegradability of a selected range of polymers and polymer blends and standard methods for assessment of biodegradation. Journal of Polymers and the Environment. v. 13, p. 231251.

MACHADO, S. A. B., REIS, O. H. J., SILVA, B. J., CRUZ, B. L. NUNES, L. I., PEREIRA, V. F. \& DRUZIAN. I. D. (2014). Obtenção de nanocelulose da fibra de coco verde e incorporação em filmes biodegradáveis de amido plastificados com glicerol. Química Nova, v. 37, n. 8.

MANO, E. B.; Polímeros como materiais de engenharia, $3^{a}$ ed., Edgard Blücher: São Paulo, 2000 .

MARENGO, V. A., VERCELHEZE, A. E. S. \& MALI, S. (2013). Compósitos biodegradáveis de amido de mandioca e resíduos da agroindústria. Química Nova, v. 36, n. 5.
MASMOUDI, F., BESSADOK, A., DAMMAK, M., JAZIRI, M. \& AMMAR, E. (2016). Biodegradable packaging materials conception based on starch and polylactic acid (PLA) reinforced with cellulose. Environmenta Science and Pollution Research, v. 23, n. 2, p. 2090420914.

MEI, L. H., \& OLIVEIRA N.(2017). Caracterização de um compósito polimérico biodegradável utilizando Poli ( $\varepsilon$-caprolactona) e borra de café. Polímeros, v. 27, p. 99-109.

MENDES, J. F., PASCHOALIN, R. T., CARMONA, V. B., NETO, A. R. S...OLIVERIA, J.E. (2012). Biodegradable polymer blends on corn starch and thermoplastic chitosan processed by extrusion. Carbohydrate Polymers, v. 137, p. 452-458.

MOURA, I., MACHADO, A. V., DUARTE, F. M., BRITO, A. G. B. \& NOGUEIRA, R. (2010). Biodegrability assessment of polyesters using standard methods. Journal of Applied Polymer Science, v. 119, p. 3338-3346.

MULLER, C. M. O., YAMASHITA, F. \& LAURINDO, J. B. (2008). Evaluation of the effects of glycerol and sorbitol concentration and water activity on the water barrier properties of cassava starch films through a solubility approach. Carbohydrate Polymers, v. 72, p. 82-87.

SALGADO, P. R., SCHMIDT, V. C., ORTIZ, S. E., MAURI, A. N. \& LAURINDO, J. B. (2008). Biodegradable foams based on cassava starch, sunflower proteins and cellulose fibers obtained by a baking process. Journal of food engineering. $v$. 85 , p. 435-443.

SUEIRO, A. C., FARIA-TISCHER. P, C, S, LONNI. A, A, S, G, \& MALI. S. (2016). Filmes biodegradáveis de amido de mandioca, pululana e celulose bacteriana. Química Nova, v.39 n. 9.

SCHMIDT, V. C. R.; LAURINDO, J. B. (2010) Characterization of foams obtained from cassava starch, cellulose fibres and dolomitic limestone by 
a thermopressing process. Brazilian Archives of Bioology and Technology, Curitiba, v.53, n.1, p. 185-192.

XIE, F., HALLEY, P. J. \& AVEROUS L. (2012). Reologia para entender e otimizar processabilidade, estruturas e propriedades de materiais poliméricos de amido. Progress in Polymer Science, v. 37, p. 595-623.

Submetido: 08/05/2020.

Aceito: 17/02/2021.

Publicado: 04/03/2021. 
